\title{
O PARADOXO DAS REFORMAS DO ESTADO DE DIREITO: QUANDO REFORMAS INICIAIS SE TORNAM OBSTÁCULOS PARA REFORMAS FUTURAS ${ }^{1}$
}

\author{
Mariana Mota Prado
}

\begin{abstract}
RESUMO
No seu livro mais recente, Reformas do Estado de Direito e Desenvolvimento: Mapeando o Difícil Caminho do Progresso, Michael Trebilcock e Ron Daniels mostram como as numerosas tentativas de promover reformas para fortalecer o Estado de Direito em países em desenvolvimento geraram poucos sucessos e muitos fracassos. $O$ diagnóstico dos autores é que fatores sociais, históricos e culturais e a resistência de grupos de interesse, foram dois dos principais obstáculos ao sucesso das reformas. O artigo oferece uma discussão mais aprofundada sobre esses dois obstáculos. A análise se baseia em dados secundários (literatura acadêmica) e apenas formula hipóteses a serem testadas. Não houve coleta de dados primários para a realização dessa pesquisa. Com relação aos fatores sociais, históricos e culturais, a hipótese é que reformas iniciais podem criar valores, práticas e atitudes que se tornarão, por vezes, impedimentos para futuras reformas. Já na arena da economia política, essas reformas iniciais podem fortalecer grupos de interesse que irão bloquear futuras reformas. Se as hipóteses estiverem corretas, os formuladores de políticas públicas encontram-se diante de um paradoxo: reformas iniciais ambiciosas podem prejudicar os esforços para promover reformas importantes no futuro, criando uma armadilha no processo de reforma (reforma-armadilha). $O$ artigo sugere que o caso da reforma do judiciário no Brasil parece ilustrar esse paradoxo e permitiria discutir possíveis estratégias para superar esse impasse.
\end{abstract}

PALAVRAS-CHAVE: teoria institucionalista; Direito e desenvolvimento; reforma do poder Judiciário; Estado de Direito; path dependence.

\section{INTRODUÇÃO²}

A partir da década de 1990, uma perspectiva institucionalista tem ganhado cada vez mais proeminência em estudos sobre o desenvolvimento. A idéia central dessa perspectiva encontra-se resumida nos seus mantras "instituições importam" ou "governança importa"3. A convicção de que a existência de instituições adequadas é um fator indispensável para

\footnotetext{
${ }^{1}$ Este artigo é uma tradução do original em inglês "The Paradox of Rule of Law Reforms: How Early Reforms Can Create Obstacles to Future Ones", publicado na University of Toronto Law Journal , volume 60, página 555-578, Spring, 2010. Tradução de Patrícia Galvão Ferreira e revisão da tradução pela própria autora.

2 Meus agradecimentos a Diego Werneck Arguelhes, Kevin Davis, Diana Juricevic, Karen Knop, Julia Cadaval Martins, Michael Trebilcock, Ilton Robl Filho e aos revisores anônimos por comentários e sugestões valiosas. Meus agradecimentos também a Patrícia Galvão Ferreira e Natasha Kanerva pela excelente assistência na pesquisa para este artigo.

3 As expressões em inglês são "institutions matter" ou "governance matters". Essa perspectiva de que instituições são o fator de influência mais importante em processos de
}

o desenvolvimento levou a um aumento significativo de assistência para projetos de reforma institucional em economias em desenvolvimento e em transição. Hoje, tais projetos somam investimentos de muitos bilhões de dólares. Dentre esses, os projetos de reforma legal adquiriram grande relevância. Por exemplo, desde 1990 o Banco Mundial apoiou 330 projetos de reforma para fortalecer o Estado de Direito em países em desenvolvimento, tendo investido US\$ 2,9 bilhões nesse setor.

No entanto, até o momento, esses numerosos projetos de reforma apresentaram resultados

\footnotetext{
desenvolvimento social e econômico está baseada fundamentalmente no trabalho de Douglas C. North, um dos fundadores da escola de pensamento conhecida como "novo institucionalismo econômico" (também conhecida pela abreviatura NIE, do original em inglês New Institutional Economics ). As teorias mais relevantes produzidas por North na área do NIE podem ser encontradas em algumas de suas obras seminais tais como Institutions, Institutional Change and Economic Performance (NORTH, 1990) e "The New Institutional Economics (NORTH, 1986) (Nota da Tradutora, doravante "NT").
} 
desapontadores, como mostraram Michael Trebilcock e Ron Daniels em seu recente livro Reformas do Estado de Direito e Desenvolvimento: Mapeando o Dificil Caminho do Progresso (TREBILCOCK \& DANIELS, 2008). Após examinar detalhadamente uma série de reformas institucionais para promover o fortalecimento do Estado de Direito na África, na Ásia, na América Latina e na Europa Oriental, os autores mostram que ainda temos pouco conhecimento sobre como promover reformas institucionais bem-sucedidas. Outros autores expressam preocupações semelhantes, mostrando que Trebilcock e Daniels não estão sozinhos (cf. CAROTHERS, 1998; 2002; GARTH \& DEZALAY, 2002; TAMANAHA, 2004; 2009; TRUBEK, 2006).

Baseados em uma ampla amostra de estudos de caso, Trebilcock e Daniels oferecem algumas hipóteses sobre as possíveis razões para esses fracos resultados. De acordo com os autores, existem três principais obstáculos às reformas. Primeiro, em países onde existe vontade política para promover reformas, faltam recursos financeiros, tecnológicos ou humanos para implementá-las. Segundo, há "fatores sociais, culturais e históricos" que podem fomentar uma série de valores, normas, atitudes e/ou práticas que são pouco receptivas até mesmo a uma versão bastante restrita do Estado de Direito (TREBILCOCK \& DANIELS, 2008, p. 39). Terceiro, existem impedimentos de economia política. Grupos de interesse resistirão a tentativas de implementar reformas que eliminem seus privilégios, ou que não favoreçam seus interesses, ou que não lhes ofereça nenhum ganho (material ou de outra natureza) (idem, p. 39-40).

Meu principal argumento, neste artigo, é que alguns desses obstáculos podem ser criados por reformas seqüenciais ou fragmentadas ${ }^{4}$. Quando as reformas são implementadas em seqüência, em vez de serem implementadas integralmente, mudanças institucionais iniciais podem gerar dois tipos de conseqüências: $(i)$ a formação de práticas, valores e atitudes que irão bloquear futuras reformas; (ii) o fortalecimento de grupos de interesse que irão resistir a futuras reformas. Para ilustrar esse problema, discuto o caso da reforma judiciária no Brasil. A Constituição Brasileira de 1988 assegurou fortes garantias de independência para o poder Judiciário brasileiro. Já em 1992 surgiram tentativas de promover reformas legais e constitucionais para aprimorar o funcionamento do

\footnotetext{
4 Neste artigo, uso as palavras "fragmentada/o" e "sequencial" indistintamente, para caracterizar uma estratégia de reforma que contrasta com projetos de reformas que são abrangentes, integrais e completos. Para uma definição mais detalhada desses termos, ver as notas 21 e 30 , abaixo.
}

poder Judiciário e aumentar sua accountability ${ }^{5}$ mas os juízes brasileiros resistiram fortemente a essas reformas. Essa resistência conseguiu bloquear reformas até 2004, quando uma emenda constitucional criando um sistema de controle externo do poder Judiciário foi finalmente aprovada.

Esse caso mostra como reformas fragmentadas ou seqüenciais podem prejudicar um processo mais completo de reformas, dado que conquistas iniciais podem paradoxalmente dificultar futuras melhorias institucionais. Chamo isso de reforma-armadilha (ver seção II, a seguir). Considerando que esse problema é parcialmente causado pela decisão de implementar reformas seqüenciais ou fragmentadas, seria correto inferir que a melhor estratégia seria evitar esse tipo de reforma? Em tese, a resposta a essa pergunta é afirmativa. No entanto, aqueles que querem promover reformas ambiciosas precisam atentar para alguns dos riscos das reformas completas e integrais. Além disso, embora reformas abrangentes sejam, em tese, a solução, muitas vezes reformas fragmentadas e seqüenciais são as únicas opções disponíveis (ver seção III, a seguir). Seria possível, nesses casos, escapar dessa armadilha? O caso da reforma do poder Judiciário no Brasil indica que sim.

Após discutir algumas das sugestões oferecidas por Trebilcock e Daniels sobre formas de superar obstáculos a reformas, formulo algumas sugestões adicionais, ressaltando uma opção que ainda não foi devidamente explorada pela literatura acadêmica: mudar a mentalidade (mindset) ou as preferências do grupo que mais está resistindo às reformas (Seção IV).

A análise aqui elaborada baseia-se em um projeto de pesquisa que desenvolvi em colaboração com Michael Trebilcock. No artigo intitulado "Path Dependence' Desenvolvimento e a Dinâmica das Reformas Institucionais" 6 , nós identificamos uma série de vantagens oferecidas por reformas fragmentadas e sequenciais (MOTA PRADO \& TREBILCOCK, 2009). Em contraste, no presente artigo eu ressalto um dos potenciais problemas com esse tipo de

5 O termo accountability é usado nesse artigo em virtude da ausência de uma tradução adequada para o significado da expressão. Os conceitos mais aproximados são o de "responsabilização" de agentes públicos, ou "prestação de contas". Para uma análise da dificuldade de traduzir esse conceito, ver Pinho e Sacramento (2009). (NT).

6 A expressão path dependence, mantida do original em inglês, é algumas vezes traduzida em português como "dependência relativa ao percurso", "dependência da trajetória" ou "dependência histórica". Path dependence significa a influência significativa de opções institucionais adotadas no passado, na trajetória presente e futura dessas instituições. (NT). 
reforma: reformas iniciais tornando-se obstáculos para futuras reformas. Entretanto, eu não concluo que reformas integrais e abrangentes sejam necessariamente preferíveis à reformas seqüenciais. Ao contrário, aqueles que estejam implementando reformas devem pesar os riscos apresentados por reformas fragmentadas em relação aos riscos apresentados por reformas abrangentes, e esses últimos não são desprezíveis.

Além disso, apesar do risco de reformas-armadilha, em alguns casos reformas fragmentadas são a única opção disponível. Em artigo sobre path dependence, Mota Prado e Trebilcock (idem) analisaram as vantagens oferecidas por reformas fragmentadas visà-vis reformas integrais durante o que nós denominamos "períodos normais". Concluiu-se que a implementação de reformas ambiciosas é improvável durante períodos normais, porque esse tipo de reforma exige grandes rupturas e causa perturbações sociais e políticas gerando, conseqüentemente, maior resistência. $\mathrm{O}$ cenário é diferente quando se trata de períodos excepcionais (que incluem períodos de crise econômica, crises políticas significativas, guerra civil ou invasões militares), porque a credibilidade e legitimidade das elites historicamente estabelecidas estão em geral enfraquecidas e os padrões de comportamento social já se encontram desestruturados. Nesses casos, reformas mais abrangentes e ambiciosas podem tornarse factíveis. Entretanto, nós reconhecemos que até mesmo em períodos excepcionais podem existir problemas de path dependence (idem, p. 370). No presente artigo, aprofundo esse argumento, explorando como alguns dos fatores econômicos, sociais e culturais pré-existentes podem criar obstáculos para reformas também em períodos excepcionais. Mais especificamente, discuto quais fatores podem tornar reformas integrais e ambiciosas em reformas custosas, arriscadas e algumas vezes improváveis, até mesmo durante períodos que deveriam, em princípio, representar "janelas de oportunidade" para reformas abrangentes. A reforma do poder Judiciário brasileiro serve de ilustração ao meu argumento.

\section{ESTUDO DE CASO: REFORMANDO O JUDI- CIÁRIO BRASILEIRO}

Desde a independência, em 1822, até o final da ditadura militar, em 1985, a história do poder Judiciário brasileiro oscilou entre conquistas de garantias formais de independência e repetidos recuos e interferências dos poderes Executivo e Legislativo na independência efetiva dos membros do poder Judiciário (LIMA, 2000). A quebra desse padrão foi uma das principais preocupações das pessoas reunidas na Assembléia Constituinte de 1987-1988, que guardavam memórias vívidas das medidas que haviam sido usadas para reduzir a independência judicial durante o período de 1964 a $1985^{7}$. Os constituintes de 1987-1988 tinham como meta assegurar altos níveis de independência judicial, tanto para proteger o poder Judiciário de ingerências políticas externas quanto para permitir que ele pudesse servir como um instrumento horizontal de controle dos outros poderes, assegurando um sistema de freio e contrapesos para conter potenciais abusos políticos dos poderes Executivo e Legislativo.

O desenho institucional utilizado para garantir a independência judicial no Brasil incluiu a concessão de autonomia financeira e administrativa para o poder Judiciário, bem como a expansão de seus poderes de revisão constitucional. As reformas de 1988 conseguiram assegurar um alto grau de independência judicial no Brasil, como demonstram as sentenças em questões políticas sensíveis e a forte imunidade do poder Judiciário a interferências externas (idem, p. 83; SANTISO, 2003; TAYLOR, 2005; 2008). No entanto, as deficiências do modelo de reforma brasileiro começaram a revelar-se logo após a promulgação da Constituição. Por um lado, o desenho institucional fortaleceu o poder Judiciário e garantiu um poder político sem precedentes para juízes e tribunais. Por outro lado, esse poder não foi submetido a qualquer controle devido à ausência quase total de mecanismos de accountability (PRILLAMAN, 2000, p. 85-88; SANTISO, 2003). As tentativas de implementar uma segunda geração de reformas, dessa vez incluindo mecanismos de accountability judicial, começaram em 1992, apenas quatro anos após a Constituição ter sido promulgada. Todavia, longos 15 anos passaram-se até que as primeiras mudanças significativas nesse sentido fossem finalmente incorporadas ao sistema jurídico brasileiro. Nesta seção, sugiro que as dificuldades em implementar uma segunda geração de reformas no poder Judiciário brasileiro tem suas raízes - ao menos parcialmente em interesses constituídos e em uma série de valores cultivados pela primeira geração de reformas. Para desenvolver esse argumento, focarei minha análise em um dos elementos da segunda geração de reformas: as tentativas para criar um órgão de controle externo do poder Judiciário no Brasil.

\section{II.1. As reformas de 1988: independência judicial sem controle externo}

A Constituição Brasileira de 1988 manteve, fortaleceu e estabeleceu uma série de garantias com vistas a proteger a independência judicial. Para evitar interferências políticas por meio de pressões ou

\footnotetext{
7 Para um resumo, ver Prillaman (2000).
} 
ameaças financeiras, o poder Judiciário ganhou autonomia financeira (PRILLAMAN, 2000, p. 81). Também ganhou independência administrativa: os tribunais superiores adquiriram o direito exclusivo de propor projetos de lei relativos à criação de novos tribunais ou à modificação da composição dos tribunais já existentes (KOERNER, 1999). Adicionalmente, a partir da promulgação da Constituição de 1988, os tribunais adquiriram o poder de selecionar e promover os próprios juízes e membros dos tribunais, seguindo um sistema meritocrático. Os constituintes de 1988 também fortaleceram as garantias de estabilidade funcional no poder Judiciário: após dois anos probatórios, os juízes adquirem garantia de estabilidade até a aposentadoria, que é mandatória no Brasil a partir dos 70 anos. Os salários dos juízes tornaram-se irredutíveis. Além disso, os juízes tornaram-se inamovíveis, sendo vedada a transferência forçada de um tribunal a outro ${ }^{8}$. Os tribunais superiores passaram a conhecer os recursos administrativos disciplinares contra os juízes de cortes inferiores, e a sanção administrativa máxima a ser aplicada por esses tribunais passou a ser a de aposentadoria forçada, que determina que o juiz condenado recebe aposentadoria integral vitalícia em valor proporcional aos anos trabalhados. Em resumo, o poder Judiciário obteve um controle quase total sobre suas questões financeiras, administrativas e disciplinares, conquistando benefícios inéditos no país (PRILLAMAN, 2000, p. 81).

Durante a Assembléia Constituinte houve discussões sobre possíveis mecanismos de accountability judicial, tais como conselhos judiciais compostos por juízes e por integrantes de fora da magistratura. Entretanto, nenhum mecanismo chegou a ser aprovado, em virtude da oposição forte e organizada de juízes que consideravam tais propostas como medidas de controle externo que iriam ameaçar a independência dos tribunais (BALLARD, 1999, p. 262). Esse receio de ingerência externa era justificado, tendo em vista que a história brasileira está repleta de episódios de intervenção política externa no poder Judiciário, incluindo o traumático período militar que antecedeu a constituinte. Por exemplo, em 1977 o então presidente Ernesto Geisel apresentou um projeto de lei ao Congresso para estabelecer o que chamou de "conselho da magistratura", que incluía poderes para disciplinar juízes (idem, p. 243). Quando o Congresso rejeitou o projeto, Geisel aprovou a medida por decreto. $\mathrm{O}$ conselho da magistratura estabelecido por Geisel

\footnotetext{
8 Lei Orgânica da Magistratura Nacional (LOMAN), art. 26, c. II.
}

tinha implícito o objetivo de assegurar maior controle político do regime militar sobre o poder Judiciário (GAROUPA \& GINSBURG, 2009, p. 69). Esse episódio, ainda recente à época da Assembléia Constituinte, ajuda-nos a entender por que o discurso em prol da independência judicial adquiriu tamanha força em 1987-1988 e por que esse discurso permaneceria veemente nos anos que se seguiram.

Além da resistência dos juízes, não havia, à época, suficiente apoio público para a criação de possíveis mecanismos de accountability do poder Judiciário. Essa ausência de apoio público pode ser explicada pelo fato de que, durante a ditadura militar, a comunidade jurídica brasileira havia adquirido uma forte imagem antiautoritária. Essa imagem estava associada à atuação firme da Organização dos Advogados Brasileiros (OAB), bem como dos advogados das comissões de justiça e paz, na denúncia de violações de direitos humanos e no lobby por uma anistia política geral e irrestrita para presos políticos. Um grupo seleto de advogados que ganharia notoriedade nacional ao defender presos políticos ilustres contribuiu especialmente para essa imagem. Por outro lado, essa percepção pública da comunidade jurídica ignorava a participação ativa de advogados e juízes no repressivo sistema de justiça militar (PEREIRA, 2003, p. 7).

\section{II.2. Conseqüências das reformas de 1988: má gestão de recursos e corrupção}

A ausência de mecanismos de accountability externos para monitorar o uso de recursos públicos, verificar os critérios de avanços na carreira e supervisionar uma série de questões administrativas e disciplinares levou à má gestão financeira, corrupção, práticas de nepotismo e favoritismo dentro do sistema judicial brasileiro (PRILLAMAN, 2000, p. 85-87; SANTISO, 2003, p. 9). Na metade da década de 1990 já havia um grande número de denúncias sobre casos de desvios de fundos, concessão de benefícios individuais indevidos ou excessivos a juízes e corrupção. Carlos Santiso cita três exemplos de má gestão ocorridos em 1994: enquanto o orçamento anual da justiça federal era de meio bilhão de dólares, o poder Judiciário gastou mais de US\$ 880 milhões naquele ano; o Tribunal Superior do Trabalho (TST) sozinho havia desembolsado mais do que ambas as casas do Congresso em apenas um ano; e a construção de um único prédio luxuoso para servir de sede ao Tribunal Superior de Justiça (STJ) havia custado US\$ 170 milhões (SANTISO, 2003).

Em relação a benefícios individuais a juízes, William Prillaman fornece a seguinte informação: “Os juízes, ao deterem o poder de determinar os próprios salários, pensões, estrutura de apoio funcional e orçamentos, 
passaram a conceder tratamento - especialmente para os escalões mais altos - excepcionalmente privilegiado, incluindo alguns dos benefícios mais generosos em todo o mundo. Um ministro do Supremo Tribunal Federal no Brasil ganha US\$ 10800 mensais - mais do que o próprio presidente - enquanto o salário médio de um juiz de primeira instância é mais de 30 vezes superior ao salário mínimo. Os juízes são ainda mais privilegiados na aposentadoria: o Tribunal de Contas do Brasil calculou que um juiz de primeira instância ganhava tipicamente US\$ 2393 mensais em 1994 quando na ativa, mas o mesmo juiz ganhava uma média de US\$ 3559 quando se aposentava - o Brasil sendo o único país do mundo em que um juiz ganha mais após aposentar-se do que quando está em serviço" (PRILLLAMAN, 2000, p. 86) ${ }^{9}$.

No final da década de 1990, vários casos de corrupção judicial ganharam destaque na mídia brasileira. O caso mais discutido foi o da construção do Tribunal Regional do Trabalho de São Paulo (TRTSP). O Juiz Nicolau dos Santos Neto, à época presidente do TRT-SP, foi acusado e posteriormente condenado por liderar um esquema de corrupção que desviou mais de US\$ 90 milhões de fundos alocados para a construção da sede do TRT-SP para contas bancárias privadas (incluindo contas em seu próprio nome e de seus familiares) (TAYLOR \& BURANELLI, 2007, p. 71). Esse e outros casos de corrupção e má gestão de recursos levaram o Senado a criar uma Comissão Parlamentar de Inquérito (CPI) para investigar abusos no poder Judiciário. A CPI, que funcionou de abril a dezembro de 1999, conduziu inquéritos sobre o caso de corrupção no TRT-SP e também sobre outros oito casos de possíveis abusos. Os resultados revelaram a extensão do problema: membros da CPI encontraram evidências de nepotismo, irregularidades financeiras e corrupção nas cortes superiores e inferiores nos estados da Paraíba, Rio de Janeiro, Mato Grosso, Goiás e Amazonas (BRASIL, 2010).

\footnotetext{
9 Tradução livre do trecho original em inglês: "Judges, empowered to set up their own wages, pension, staffing requirements, and budgets, have treated themselves particularly their upper ranks - exceptionally well, with some of the world's most generous benefits. A Supreme Court justice earns US\$10,800 monthly - more than the President himselfwhile an average judge of first instance earns more than thirty times the national minimum salary. Judges do even better in retirement; Brazil 's National Accounting Office has calculated that a typical judge of first instance earned US $\$ 2,393$ monthly in 1994 when serving on bench, but US\$ 3,559 when he retired - the only country in the world in which a judge earns more in retirement than when serving on the bench" (NT).
}

II.3. Resistência a Reformas: de 1988 até o Final dos Anos 90

Como mencionado anteriormente, as tentativas de criar mecanismos de maior controle do poder Judiciário foram iniciadas logo após a promulgação da Constituição de 1988. No entanto, a primeira reforma significativa (Emenda Constitucional 45) só viria a acontecer em 2004, e só após sete anos de intensa pressão política. Por que as reformas para garantir mais accountability para o poder Judiciário brasileiro levaram tanto tempo para ser aprovadas?

Trebilcock e Daniels dividem os possíveis obstáculos ou impedimentos para a implementação de reformas do Estado de Direito em países em desenvolvimento em três categorias: $(i)$ impedimentos financeiros; (ii) fatores sociais, políticos e culturais e (iii) problemas de economia política (TREBILCOCK \& DANIELS, 2008, p. 39). No primeiro caso, os principais atores teriam vontade política, mas a ausência de capital financeiro, tecnológico ou humano impediriam a implementação dessas reformas. No entanto, a falta de recursos não parece ter sido um problema para o poder Judiciário brasileiro. Os tribunais federais brasileiros são "bem financiados em regra, com o maior orçamento em termos de paridade de poder de compra per capita quando comparado aos outros sistemas federais de todo o hemisfério ocidental" (TAYLOR, 2008, p. 37) ${ }^{10}$.

Trebilcock e Daniels argumentam que uma série de valores sociais, normas, atitudes e práticas, o que eles classificam em uma categoria vagamente definida de fatores históricos-sociais-culturais, podem formar um ambiente hostil para a implementação de reformas. A crença exacerbada no valor superior da independência judicial vis-à-vis a necessidade de garantir accountability ao poder Judiciário pode ter exercido influência na resistência que juízes brasileiros ofereceram às tentativas de reformas após 1988 . Conforme explicitado anteriormente, essa crença havia sido reforçada pela história recente do país, já que reformas que supostamente promoveriam maior accountability foram utilizadas para enfraquecer a independência do poder Judiciário ${ }^{11}$. A percepção pública positiva do poder Judiciário como um bastião

\footnotetext{
10 As cortes estaduais não contam necessariamente com o mesmo acesso à recursos abundantes. Tradução livre do original em inglês: "well funded as a whole, with the highest budget in purchasing power parity terms per inhabitant of all the federal systems in the Western hemisphere" (NT).

11 Cf. Ballard (1999, p. 262) e Prillaman (2000, p. 81). Ver também Garoupa e Ginsburg (2009a, p. 60), sugerindo que essa não é uma característica exclusiva do Brasil.
} 
da proteção dos direitos humanos e da promoção do interesse público durante a ditadura militar também reforçou essa crença na importância de preservar a independência judicial contra a interferência indevida dos outros poderes a qualquer custo.

Há também razões para acreditar que interesses constituídos de membros do poder Judiciário brasileiro (classificados como obstáculos de economia política) exerceram um papel importante na resistência a reformas. Usando a tipologia de obstáculos a reformas, criada por Trebilcock e Daniels, levanta-se aqui a hipótese de que, no Brasil, esses impedimentos de economia política, paradoxalmente, foram criados ou significativamente fortalecidos pela primeira geração de reformas em 1988.

As propostas mais específicas para criar algum tipo de mecanismo de controle externo do poder Judiciário começaram ainda em $1992^{12}$. Os debates tornaram-se mais intensos durante o processo de revisão constitucional ocorrido em 1993, quando 12 das 18 propostas de reforma do poder Judiciário incluíram algum mecanismo externo de controle (PRILLAMAN, 2000). Nenhuma dessas propostas foi bem sucedida. Assim como as outras propostas de revisão constitucional em 1993, a discussão sobre a reforma do poder Judiciário foi ofuscada pela turbulência política gerada pelo escândalo de corrupção envolvendo 29 membros do Congresso Nacional (POWER, 1997). Pouco antes desse escândalo, o Congresso Nacional brasileiro havia aprovado o processo de impeachment do então presidente Fernando Collor de Mello, em virtude de denúncias de corrupção no poder Executivo ${ }^{13}$. Esses acontecimentos terminaram por privar tanto o poder Executivo quanto o poder Legislativo da reputação, do prestígio e da influência arduamente conquistados no período da Assembléia Constituinte (LAMOUNIER, 1994). Essas circunstâncias políticas prejudicaram a habilidade dos membros desses poderes de contribuírem para a aprovação de reformas judiciais significativas.

Além desse contexto político conturbado, juízes e membros dos tribunais exerceram um papel importante no bloqueio das tentativas de reforma, alegando que as mudanças iriam ameaçar a independência judicial (PRILLAMAN, 2000). Essa posição do poder Judiciário à época contrastava com o amplo apoio às

12 Para uma análise detalhada dessas propostas, cf. Rosenn (2000).

13 Para um estudo mais aprofundado sobre esse tema, ver Mainwaring (1997, p. 94-97). reformas de outros setores da sociedade brasileira. $\mathrm{O}$ poder Executivo, a maioria dos parlamentares, a Ordem dos Advogados do Brasil (OAB), outras organizações da sociedade civil e os sindicatos, todos expressaram apoio à idéia do controle externo do poder Judiciário ${ }^{14}$. De fato, após 1993, várias propostas de revisão constitucional que incluíam a criação de um conselho nacional para monitorar o poder Judiciário continuaram a ser apresentadas e discutidas por representantes do Congresso ${ }^{15}$. No entanto, a maioria dos juízes continuou a opor-se à idéia e nenhuma das propostas foi aprovada. Megan Ballard discute a resistência dos juízes durante esse período em maiores detalhes. Em suas palavras: “[...] membros da Associação dos Juízes para a Democracia unanimemente se opõem a qualquer tipo de controle que possa interferir com a liberdade de cada juiz de decidir. Uma pesquisa com juízes indicou que $86,5 \%$ deles se opõem ao controle externo do Judiciário. A Associação dos Magistrados do Brasil (AMB) fez lobby contra o controle externo, afirmando que a proposta equivalia a uma aberração constitucional e alegando que a medida menosprezava os juízes. Da mesma forma, a maioria dos ministros do Supremo Tribunal Federal são contra o controle externo, dado que afetaria a independência judicial, e propuseram, ao invés disso, a criação de uma série de 'controles internos' por meio de um conselho formado por juízes das cortes superiores" (BALLARD, 1999, p. 263)16.

Dado um sistema que permitia tantos privilégios e fechava os olhos para tantos abusos dentro do poder Judiciário, parece plausível assumir que interesses

\footnotetext{
14 Prillaman (2010, p. 94) escreve que "entre 1994-95, 74\% do Congresso declarou apoiar o controle externo do Judiciário, enquanto $72 \%$ do público expressou a mesma opinião" (tradução livre). Ver também Ballard (1999).

15 Em 1995, José Genoino, filiado ao Partido dos Trabalhadores (PT), apresentou uma proposta para a criação de conselhos estaduais e um conselho federal para supervisionar os trabalhos financeiros e administrativos do poder Judiciário. A Câmara dos Deputados apresentou uma proposta alternativa, em 1996, para a criação de um Conselho Nacional de Justiça para supervisionar assuntos internos e receber reclamações contra o poder Judiciário.

16 Tradução livre do original em inglês: "Members of the Association of Judges for Democracy unanimously oppose any type of control that would interfere with the liberty of each judge to render his or her decisions. A survey of judges indicated that $86.5 \%$ of judges oppose external control over the judiciary. The Association of Judges of Brazil (Associação dos Magistrados do Brasil, or AMB) lobbied against external oversight, calling the measure unconstitutional 'nonsense' and claiming that it devalued judges. Likewise, most STF justices oppose external control on the grounds that it impairs judicial independence and have instead proposed a series of "internal controls' by a council made up of appellate judges" (NT).
} 
estabelecidos exerceram um papel importante no posicionamento dos membros do poder Judiciário com relação às reformas.

Em síntese, desde 1992 existia uma forte pressão para que fosse implementada alguma forma de conselho independente para exercer o controle externo do poder Judiciário no Brasil. No entanto, por muitos anos o próprio Judiciário resistiu firmemente a propostas de reforma nesse sentido. Essa resistência foi baseada primordialmente em três fatores. Primeiro, havia uma crença arraigada no valor da independência judicial, um elemento central no discurso contra as primeiras tentativas de reforma, e tal crença moldou as práticas e atitudes dos membros do poder Judiciário desde 1988. Segundo, os juízes não estavam dispostos a permitir que outros poderes pudessem interferir na ampla autonomia e nos privilégios que eles haviam conquistado com a Constituição de 1988. Terceiro, a independência excessiva combinada com a falta de accountability abriu espaço para corrupção e outras práticas escusas e aqueles que estavam aproveitandose dessas brechas não estavam dispostos a abrir mão dos interesses e benefícios adquiridos.

\section{II.4. Criação do Conselho Nacional de Justiça (2005)}

O final da década de 1990 marcou o início de uma mudança gradual na posição de algumas das associações de juízes que representam os interesses da magistratura, e uma parcela do poder Judiciário brasileiro passou a aceitar a idéia de um mecanismo de controle. No entanto, persistiu a resistência à inclusão de membros externos ao poder Judiciário (idem, p. 264). Essa mudança no posicionamento de parte dos magistrados brasileiros coincidiu com a eleição do presidente Luiz Inácio "Lula" da Silva, em 2002, que fez da reforma do poder Judiciário uma de suas prioridades de governo ${ }^{17}$. Em 2003, Lula criou a Secretaria de Reforma do Judiciário (SRJ) no âmbito do Ministério da Justiça, para avançar uma proposta governamental de reforma que incluía maior accountability para o poder Judiciário na forma de um órgão de controle externo ${ }^{18}$. Foi nesse contexto que a proposta de criação do Conselho Nacional de Justiça (CNJ) foi aprovada pelo Congresso Nacional, em dezembro de 2004, vindo o mesmo a ser implementado em 2005. O CNJ ganhou as atribuições

17 Garoupa e Ginsburg (2009a, p. 70) discutem as possíveis razões pelas quais o governo Lula apoiou essa reforma.

18 A agenda governamental para a reforma do poder Judiciário incluía, além da accountability, eficiência e acesso à justiça. Para um relato sobre as dificuldades enfrentadas pelo secretário, ver Oliveira (2006, p. 137-138). de monitorar a gestão administrativa e financeira dos tribunais, bem como de aplicar sanções disciplinares aos membros do poder Judiciário. Além disso, o CNJ ficou responsável por compilar e publicar estatísticas sobre o volume de trabalho e a produtividade do poder Judiciário ${ }^{19}$.

Inicialmente, o poder Judiciário opôs-se à idéia de um conselho que incluísse membros externos à magistratura, mas sua proposta em favor de um conselho eminentemente formado por magistrados foi derrotada. O CNJ é composto por nove magistrados, dois membros do Ministério Público, dois advogados indicados pelo Conselho Federal da OAB e dois cidadãos de notável saber jurídico que são nomeados pelo poder Legislativo. Apesar de contar com uma ampla maioria de membros do poder Judiciário, ainda houve resistência da magistratura a esse desenho institucional, mesmo após a criação do $\mathrm{CNJ}$. A Associação dos Magistrados Brasileiros (AMB) apresentou uma ação direta de inconstitucionalidade contra a emenda constitucional que criou o conselho, alegando que a inclusão de membros indicados pelo poder Executivo e pelo poder Legislativo feria o princípio da separação dos poderes e a independência do poder Judiciário, ambos protegidos pela Constituição de 1988. Por sete votos a quatro, o STF decidiu pela constitucionalidade do $\mathrm{CNJ}$, em abril de $2005^{20}$.

\section{III. É POSSÍVEL EVITAR PARADOXOS E ARMA- DILHAS EM REFORMAS DO ESTADO DE DIREITO?}

Na seção II, mostrou-se que o caso da reforma do poder Judiciário brasileiro ilustra uma reformaarmadilha, dado que reformas iniciais serviram de obstáculos para reformas futuras. Essas armadilhas tendem a ocorrer com reformas fragmentadas ou seqüenciais, que podem ser definidas como reformas que focam em uma única meta ou em um objetivo, como promover independência judicial. Esse tipo de reforma contrapõe-se a reformas integrais, que incluem diversos objetivos, tais como a criação de um poder Judiciário ao mesmo tempo independente, accountable, eficiente e eficaz ${ }^{21}$. Nesta seção,

\footnotetext{
19 Emenda Constitucional n. 45, de 2004 (EC-000.045-2004); Constituição Brasileira de 1988, artigos 92 I-A e 103-B.

20 Ação Direta de Inconstitucionalidade 3367/2004.

21 Existe uma distinção entre o planejamento de reformas fragmentadas (o plano inicial é o de implementar reformas abrangentes, mas de maneira gradual) e um processo de tentativas envolvendo erros e acertos em que futuras reformas não são previamente planejadas, mas dependem do que
} 
pergunta-se se uma solução para o problema de reformas-armadilha poderia ser a implementação de reformas integrais no lugar de reformas fragmentadas. Discute-se essa questão no contexto específico de projetos de reforma do poder Judiciário, mostrando que reformas integrais e abrangentes apresentam seus próprios riscos e, portanto, não são necessariamente preferíveis a reformas fragmentadas e seqüenciais. Além disso, existem circunstâncias em que reformas integrais não são uma opção, pois path dependence pode limitar o número de estratégias de reforma possíveis e tornar algumas opções impossíveis. Esse parece ter sido o caso do processo de reforma judicial brasileiro.

\section{III.1. Reformas integrais e seus riscos}

O problema enfrentado por constituintes brasileiros em 1988 não foi simples. A questão de como melhor equilibrar os princípios de independência judicial e accountability judicial permanece bastante controversa, tanto na teoria quanto na prática de políticas públicas. Pesquisadores têm discutido, por exemplo, quais aspectos específicos da independência judicial devem ser promovidos e protegidos (FISS, 1993; LARKINS 1996, p. 623) e qual grau de independência é desejável (PRILLAMAN, 2000) ${ }^{22}$. Na realidade, esses dois objetivos estão em tensão permanente, dado que mecanismos de accountability que permitem o controle e a punição de integrantes do poder Judiciário podem ser utilizados de modo abusivo e mal intencionado, reduzindo o grau de independência dos tribunais (PEREZ-PERDOMO, 2000) ${ }^{23}$. Aqueles que tentam implementar reformas enfrentam o desafio de encontrar uma forma de garantir um equilíbrio entre esses dois objetivos, tendo em vista que tanto a independência quanto accountability são fundamentais

acontecer no decorrer do processo. Como sugerido por Garoupa e Ginsburg (2009a), a criação de conselhos judiciais pode ter sido o resultado de um processo de erros e acertos em que reformas subseqüentes são desenhadas para lidar com problemas criados por reformas iniciais. Ver também Garoupa e Ginsburg (2009b). Não fica claro se o caso brasileiro encaixase na primeira ou na segunda hipótese. No entanto, é importante reconhecer que, se as reformas brasileiras seguiram um processo de erros e acertos, alguns dos problemas identificados no presente artigo seriam uma conseqüência natural desse processo, e não um erro que poderia ter sido evitado em um processo planejado de reformas graduais e seqüenciadas. A distinção merece uma análise mais aprofundada, que está, no entanto, além do objetivo deste artigo.

22 Ver também Sutil (1993).

23 Trebilcock (1997) mostra que existe uma tensão permanente entre autonomia institucional e accountability institucional em outras áreas, como a burocracia. para um poder Judiciário funcional ${ }^{24}$. Em outras palavras, aqueles preocupados com reformas muitas vezes encontram-se em uma encruzilhada ao tentar equilibrar dois objetivos políticos que podem ser facilmente conflitantes ${ }^{25}$. Nesses casos há pelo menos duas opções: $(i)$ tentar promover os dois objetivos simultaneamente, tentando alcançar de imediato um equilíbrio entre eles ou ( $i$ i) favorecer um objetivo em detrimento do outro, ainda que temporariamente. Enquanto a primeira opção caracteriza uma estratégia de reforma integral, a segunda opção caracteriza um processo de reforma fragmentado ou seqüencial.

A estratégia fragmentada é intuitivamente atraente: ela parece ser simples, evitando "um esforço demasiadamente grande que possa limitar a capacidade estatal e gerar o risco de perder-se no meio de muitas iniciativas levadas a cabo ao mesmo tempo" (PRILLAMAN, 2000, p. 77-78). No entanto, favorecer um objetivo em detrimento de outro (ainda que temporariamente) também gera riscos significativos. No caso de reformas judiciais, por exemplo, se a accountability for favorecida, existe um risco maior de que grupos externos tentarão influenciar as decisões judiciais, fazendo com que sejam adotadas decisões mais populares, ou mais politicamente aceitáveis, ou até mesmo aquelas que gerem vantagens pessoais (TARR, 2006). Por outro lado, se a opção escolhida for a de promover maior independência judicial, há o risco de que os juízes obtenham liberdade excessiva e que venham a abusar dessa liberdade para promover agendas pessoais, profissionais ou políticas que não vão de encontro aos objetivos do Estado de Direito (idem; FEREJOHN \& KRAMER, 2002).

Prillaman oferece exemplos concretos desses dilemas quando faz um estudo comparado das reformas judiciais na Argentina, no Brasil e em El Salvador. Esses três casos ilustram como a estratégia de eleger um objetivo apenas em cada etapa gera o fortalecimento desse mesmo objetivo em longo prazo, enquanto os outros objetivos em geral permanecem negligenciados. Isso termina por prejudicar o projeto global de reforma, criando o que Prillaman denomina de "sinergia negativa". Para Prillaman (2000), a convicção de que o foco em um objetivo levaria inevitavelmente a reformas de outros objetivos no decorrer do processo é fundamentalmente equivocada. $\mathrm{O}$ caso do Chile indica que reformas integrais são

\footnotetext{
24 Para um mapeamento dos argumentos a favor de maior accountability, ver Tarr (2006).

25 Para uma discussão mais detalhada de como formuladores de políticas públicas podem ser constrangidos por objetivos políticos conflitantes, ver Prado (2008, p. 8).
} 
preferíveis a reformas sequenciadas (idem). No Chile, as reformas focaram no que Prillaman (idem) descreve como os componentes principais da reforma judicial - independência, eficiência e acesso - ao mesmo tempo em que buscaram manter um equilíbrio entre esses objetivos e a accountability judicial. $\mathrm{O}$ autor afirma que, nessa estratégia, "nenhum obstáculo se revelou demasiado e nenhuma reforma isolada foi prejudicada por aspectos do poder Judiciário que haviam ficado fora das reformas; em resumo, não houve sinergia negativa como em outros casos" (idem, p. 138$)^{26}$.

Conforme proposto acima, reformas fragmentadas também impõem outro risco: reformas iniciais que favorecem a independência judicial podem gerar obstáculos significativos para conseguir promover accountabilitty judicial no futuro (a reformaarmadilha). $\mathrm{O}$ risco não se restringe a reformas do poder Judiciário, mas se estende a outros tipos de reformas fragmentadas. Por exemplo, Susan RoseAckerman argumenta que, se sociedades recém-saídas de um conflito não implementarem reformas para combater corrupção nos primeiros estágios da transição, o ciclo vicioso da corrupção pode tornarse muito difícil de ser controlado em um momento posterior (ROSE-ACKERMAN, 2008).

Prillaman (2000) argumenta que reformas integrais reduzem os riscos de provocar conseqüências indesejadas. $\mathrm{O}$ autor reconhece o fato de que algumas reformas são vitoriosas porque "mecanismos de autoreforço" 27 contribuem para consolidar as mudanças institucionais implementadas ${ }^{28}$. No entanto, Prillaman aparentemente ignora que reformas integrais algumas vezes funcionam bem, como ocorrido no Chile, mas elas costumam envolver a transformação simultânea

26 Tradução livre do original em inglês: "No setback was overwhelming and no isolated reform was undermined by the unreformed aspects of the courts; in short, there was no negative synergy as in the other cases" (NT).

${ }^{27}$ No original em inglês, self-reinforcing mechanisms, um termo bastante utilizado na literatura sobre path dependence, indicando em linhas gerais que, uma vez adotado, um caminho institucional passa a gerar retornos crescentes e a tornar-se cada vez mais difícil de abandonar, em virtude de uma série de mecanismos que tendem a reforçar a escolha inicial. Esses mecanismos incluem, por exemplo, investimentos iniciais não recuperáveis (também conhecidos como sunk set up costs), efeitos de aprendizado, efeitos de coordenação, expectativas adaptativas etc. (NT).

28 Para uma explicação sobre os chamados mecanismos de auto-reforço e o papel que os mesmos desempenham nos processos de reforma institucional, ver Prado e Trebilcock (2009, p. 350-353). de vários elementos, sendo difícil prever como essa multiplicidade de mudanças irá interagir no caso concreto. Prillaman reconhece, acertadamente, que em reformas seqüenciais um mecanismo institucional recém-implementado não irá necessariamente tornarse "auto-reforçador" (isto é, não há garantias de que outras reformas irão naturalmente seguir-se às primeiras). Entretanto, o mesmo raciocínio aplica-se às reformas integrais: não há garantias de que a interação das várias mudanças institucionais simultâneas irá necessariamente produzir o resultado planejado. De fato, Prillaman apresenta o caso isolado da reforma judicial chilena para sustentar o seu argumento. A análise de Prillaman não nos permite, no entanto, concluir que, caso Brasil e Argentina tivessem seguido a mesma fórmula de reforma integral adotada pelo Chile, esses países teriam necessariamente um poder Judiciário melhor do que o que eles possuem atualmente. Em suma, não há garantias de que a estratégia de reforma chilena produziria resultados semelhantes em outros países.

Além disso, os efeitos de reformas integrais podem ser extremamente desestabilizadores e algumas vezes difíceis de reverter, o que torna ainda mais preocupante o risco de resultados indesejados (PRILLAMAN, 2000, p. 367$)^{29}$. Esses efeitos podem superar os riscos gerados pelas armadilhas de reformas fragmentadas. Em virtude disso, reformas fragmentadas podem ser preferíveis a reformas integrais em algumas circunstâncias ${ }^{30}$. Conseqüentemente, aqueles que promovem reformas devem estar conscientes de que a seqüência em que as reformas fragmentadas são realizadas é um aspecto importante da estratégia de mudança institucional, dado que algumas seqüências podem oferecer mais riscos de gerar armadilhas do que outras (PRADO \& TREBILCOCK, 2009).

29 É verdade que Prillaman rejeita a idéia de incrementalismo seqüencial, no entanto, esse autor favorece reformas que são abrangentes em escopo, mas graduais na implementação (PRILLAMAN, 2000, p. 77-78).

30 Existem reformas integrais que incluem objetivos múltiplos, mas que são limitadas geograficamente ou em termos de setor ou instituição de foco. Por exemplo, em alguns estados federais é possível teorizar que o governo federal tem poder para reformar cortes no âmbito estadual. Esse governo federal pode decidir implementar reformas nas cortes de um único estado; de modo semelhante, o governo federal pode implementar reformas apenas em cortes especificas, tais como juizados de pequeno porte, no lugar de promover mudanças no sistema judiciário como um todo. Essas delimitações, em termos de escopo e dimensão, podem trazer essas reformas mais para o modelo de reformas fragmentadas ou parciais, no sentido de que esse modelo traz menos riscos do que reformas integrais e abrangentes que são implementadas em toda a extensão do país e para o sistema judicial como um todo. 
Claramente, a seqüência específica de reformas adotada pelos constituintes brasileiros gerou uma armadilha de reforma. Ainda assim é preciso questionar se havia qualquer outra opção disponível diante das circunstâncias. Teria sido possível aos constituintes brasileiros exercer uma escolha entre reformas integrais e reformas seqüenciais nesse caso, como Prillaman parece indicar? Eu discuto essa questão na seção a seguir.

\section{III.2. Casos em que reformas seqüenciais são a única opção}

Nessa seção eu sustento que o fenômeno conhecido como path dependence pode criar obstáculos para a implementação de reformas integrais, já que fatores econômicos, sociais e culturais pré-existentes podem impor significativos custos de conversão (switching costs) a outro regime institucional (idem, p. 370). Tendo em vista esses obstáculos, é possível argumentar que, em certos contextos históricos, reformas fragmentadas podem ser a única opção disponível.

Anthony Pereira analisou como o fenômeno do path dependence pode constranger significativamente as opções disponíveis àqueles promovendo reformas que tentam fortalecer o Estado de Direito em países em transição democrática. Ele mostra como mudanças institucionais implementadas nos sistemas legais e no poder Judiciário durante os regimes autoritários influenciaram, constrangeram ou facilitaram reformas judiciais subsequentes, implementadas durante períodos democráticos ou pós-autoritários (PEREIRA, 2003). Assim como Prillaman (2000), Pereira (2003) analisa os casos da Argentina, Brasil e Chile, argumentando que as reformas judiciais implementadas nesses países após a redemocratização foram influenciadas pelo fenômeno de path dependence. Sobre o caso da reforma judicial brasileira, Pereira afirma que: "O regime militar Brasileiro de 1964-1985 foi gradualista em sua postura em relação a legislação, e havia um amplo consenso civil-militar na esfera legal. [O regime] não foi altamente repressivo em seu uso de violência letal, e essa combinação de fatores contribuiu para uma transição gradual e consensual em que a reforma judicial não constava entre os pontos prioritários da agenda (idem, p. 3-4) (1) $^{31}$.

\footnotetext{
31 Tradução livre do original em inglês: "The Brazilian military regime of 1964 - 1985 was gradualist in its approach to the law, and had a high degree of civilian - military consensus in the legal sphere. It was not highly repressive in its deployment of lethal violence, and this combination of factors contributed to a gradualist and consensual transition in which judicial reform was not placed high on the political agenda" (NT).
}

Nesse sentido, o caso brasileiro contrastou com as ditaduras mais violentas ocorridas na Argentina e no Chile. De acordo com Pereira, "o fato de que o número de pessoas afetadas pela repressão foi marcadamente menor, em termos per capita, do que na Argentina e no Chile, também reduziu a possibilidade de que houvesse uma forte reação contra o poder Judiciário no período pós-transição" (idem, p. 7) ${ }^{32}$. Na Argentina, em contraste, as reformas no período de transição democrática foram especificamente utilizadas como uma reação energética contra os poderes existentes nas esferas legal e política.

Usando o argumento apresentado por Pereira como base, sugere-se que o path dependence limita as opções possíveis de reforma ao influenciar (ou determinar) as posições de barganha no momento da reforma. As reformas judiciais no Brasil podem ser caracterizadas como um processo de barganha entre um grupo exigindo reformas e outro grupo resistindo reformas (alguns propondo e outros resistindo à criação de mais accountability). Entretanto, essa não representa uma descrição acurada da situação durante o processo de barganha da Assembléia Constituinte. Naquele momento, ambos os grupos queriam que fossem implementadas reformas. O único ponto de divergência era o fato de que, enquanto um grupo queria mais independência, o outro grupo também enfatizava a inclusão de mecanismos de accountability.

Se essa descrição é acurada, a estrutura do processo de barganha durante a Assembléia Constituinte de 1987-1988 pode ser equiparada ao que Amartya Sen denomina de "conflitos cooperativos" no contexto da instituição familiar. Sen alega que os cônjuges mantém uma relação de "conflito cooperativo": eles valorizam os benefícios mútuos da relação, ao mesmo tempo em que existem pontos em que os interesses individuais estão em conflito (SEN, 1990). Dessa forma, decisões familiares refletem o equilíbrio de interesses comuns e a barganha em relação aos interesses em conflito. $\mathrm{O}$ resultado do processo de barganha pode ser razoavelmente igualitário ou não. Essa noção de "conflitos cooperativos" descreve adequadamente o processo de reforma judicial no Brasil porque no momento da Assembléia Constituinte as reformas serviam tanto aos interesses dos juízes que privilegiavam independência judicial - quanto aos

\footnotetext{
32 Tradução livre do original em inglês: "The fact that the number of people affected by the repression was much less, in per capita terms, than in Argentina and Chile, also diminished the possibility of a backlash against the judiciary in the posttransition era" (NT).
} 
interesses de grupos que queriam independência, mas promoviam também mecanismos de accountability ${ }^{33}$.

Que fatores podem determinar qual grupo terminará por ser favorecido pelos resultados do processo de barganha? De acordo com Sen, no contexto familiar, o poder relativo de barganha das partes afeta o resultado (quanto mais desigual o poder de barganha, mais desigual tende a ser o resultado) (idem, p. 133). Esse poder relativo de barganha é determinado em parte pela posição relativa de cada parte no status quo. Nas palavras de Sen, "uma colocação mais favorável caso a negociação não seja bem sucedida [breakdown position] tende a ajudar a assegurar um resultado mais vantajoso na barganha" (idem, p. 135). Isso pode explicar alguns resultados distributivos desiguais no contexto familiar, como por exemplo o fato de que em muitos países as mulheres terminam sem acesso a qualquer renda ou capital após o divórcio. A posição relativa na estrutura institucional existente também pode explicar a reforma judicial no Brasil, tendo em vista que o poder Judiciário não tinha muito a perder por simplesmente manter o status quo: o poder Judiciário brasileiro já era um dos mais independentes da América Latina durante o período da ditadura militar (ao menos formalmente) (PEREIRA, 2008). Além disso, no caso brasileiro as preferências do poder Judiciário são especialmente importantes, já que durante a assembléia constituinte a maior parte das propostas de reforma judicial havia sido delegada para um grupo experiente de profissionais do Direito, que incluía membros do poder Judiciário, da $\mathrm{OAB}$, e de grupos de direitos humanos (PRILLAMAN, 2000, p. 79-80). Conseqüentemente, os membros do poder Judiciário foram capazes de negociar as reformas diretamente com membros de outros grupos de interesse, dado que políticos com poder de voto não

33 Se considerarmos que em ambos os casos a questão não está no se, mas sim no como, a analogia revela-se ainda mais pertinente. No caso de reformas judiciais, a questão para formuladores de políticas públicas não é se há ou não a necessidade de implementar reformas. A questão que se coloca é: entre as possíveis alternativas para reforma, qual a mais adequada? O mesmo acontece em relação à situação familiar. Nas palavras de Sem, "mulheres buscando uma situação melhor dentro do ambiente familiar não estão propondo alternativas à possibilidade de prescindir da convivência familiar. O cerne da disputa reside na questão se a divisão dos benefícios dentro do sistema familiar revela-se seriamente desigual no atual arranjo institucional, quando comparada a outros arranjos institucionais potencialmente viáveis" (SEN, 1990, p. 135-136). Tradução livre do original em inglês: "women seeking a better deal within the family are not proposing, as an alternative, the possibility of living without families. The bone of contention is whether the sharing of the benefits within the family system is seriously unequal in the existing institutional arrangements, compared with what alternative arrangements can be made". demonstraram muito interesse na reforma judicial e iriam, provavelmente, aceitar as decisões do grupo diretamente envolvido na negociação ${ }^{34}$. Também é importante ressaltar que, no caso da transição democrática brasileira, um compromisso político havia permitido ao poder Judiciário manter em tribunais superiores diversos magistrados que tinham conexões políticas com o regime militar (PRILLAMAN, 2000; SANTISO, 2003; TAYLOR, 2005; 2008). Dessa forma, entre os membros do poder Judiciário havia pessoas influentes que teriam tido algum vínculo com o regime militar (KOERNER, 1999). Isso também reforça a idéia de que, mesmo em períodos extraordinários, existe um componente de path dependence na economia política das reformas no Estado de Direito.

Em relação a fatores sociais, culturais e históricos, Sen identifica três tipos de fatores que influenciam o resultado do processo de barganha no âmbito da instituição familiar: percepções de interesse, concepções de trabalho produtivo e noções de legitimidade ${ }^{35}$. É possível encontrar fatores análogos para explicar as reformas judiciais de 1988 no Brasil. No que diz respeito à percepção de interesses ${ }^{36}$, havia uma clara falta de interesse público nas reformas judiciais (PRILLAMAN, 2000, p. 95). Aparentemente, a população brasileira não considerava que a eventual falta de controle ou acesso à informação sobre as atividades do poder Judiciário iria provocar consequências sérias ${ }^{37}$. Como mencionei anteriormente, Pereira (2003) sugere que o sistema legal brasileiro gozava de uma imagem positiva, uma

\footnotetext{
34 Para uma discussão detalhada sobre a estrutura dessa barganha, ver Pilatti (2008).
}

35 De maneira simplificada, podemos afirmar que esses três fatores podem afetar a barganha das seguintes formas: dependendo da percepção de interesses, que são fundamentalmente definidas culturalmente, mulheres podem prescindir de uma percepção de valor do próprio bem-estar individual, e isso pode estar associado a uma preocupação maior com o bem-estar familiar; com relação a concepções sobre trabalho produtivo, algumas concepções sociais comuns avançam a idéia de que o trabalho não remunerado das mulheres no contexto familiar é hierarquicamente inferior ao trabalho remunerado realizado fora do lar; em relação a noções de legitimidade, mulheres podem não se sentir merecedoras de uma parcela adicional da riqueza familiar.

36 Isso é diferente do conceito de interesses arraigados ou enraizados (entrenched interests) discutido por Trebilcock e Daniels (2008). Esses autores identificam interesses "reais", enquanto Sen (1990) propõe haver uma dissonância entre interesses "reais" e interesses percebidos subjetivamente.

37 É importante distinguir entre interesses percebidos subjetivamente e interesses "reais" (idem, p. 126). A falta de demanda popular por mecanismos de accountability não deve ser interpretada como uma ausência de interesses "reais". 
imagem antiautoritária. No que diz respeito às concepções de valores, alguns atores promovendo reformas argumentaram que existia uma hierarquia de valores entre independência e accountability, independência sendo superior. Assim, tendo em vista a natureza técnica da função judicial, mecanismos de accountability judicial não passariam de indevida interferência política ${ }^{38}$. Finalmente, noções de legitimidade também parecem ter afetado a barganha durante as reformas judiciais de $1988^{39}$. Nas palavras de Pereira: "No Brasil, em contraste com Argentina e Chile, os formuladores de políticas públicas não podiam tirar proveito de uma percepção generalizada entre a classe política de que o poder Judiciário havia falhado na sua missão de proteger a democracia dos militares e de que portanto estaria de alguma forma envenenado pelo passado autoritário. Ainda que houvesse uma percepção de ineficiência generalizada, os formuladores de políticas públicas tiveram dificuldade em vincular democratização com reforma do poder Judiciário" (idem, p. 9) ${ }^{40}$.

As dificuldades em convencer as elites políticas brasileiras de que uma reforma judicial profunda era necessária podem ser parcialmente explicadas também pelo fato de que essa elite política incluiria um novo presidente com fortes laços com o regime militar e pouco interesse no poder Judiciário, e uma classe política civil que nutria interesses oportunistas e patrimonialistas, estando mais interessada em obter os benefícios associados ao aparelho estatal do que propriamente em construir uma série de instituições de Estado que fosse accountable ao resto da sociedade (PRILLAMAN, 2000, p. 95). Aqueles suficientemente corajosos para confrontar o governo militar por suas violações de direitos humanos, do Estado Democrático de Direito e da soberania nacional, eram oradores eloqüentes, mas não necessariamente habilitados na arte de identificar e

38 Esse pressuposto tem origem na idéia de que juízes são profissionais altamente educados e qualificados, com conhecimento especializado em seu campo de trabalho. Sujeitar esses profissionais a controle não técnico e não qualificado é freqüentemente percebido como uma interferência indevida e desnecessária no seu trabalho.

39 De acordo com Sen (idem), dentro do âmbito familiar existem percepções de interesse e noções de legitimidade. Por exemplo, é difícil para uma mãe conceber se é mais legitimo alimentar a si própria ou privar-se de alimentação em beneficio da família.

40 Tradução livre do original em inglês: "In Brazil, unlike in Argentina and Chile, reformers could not tap a sense among political elites that the judiciary had failed to protect democracy from the military and was somehow tainted by an authoritarian past. While a perception of the judiciary as inefficient was widespread, reformers had difficulty linking democratization with judicial reform" (NT). representar a opinião dos cidadãos (SKIDMORE, 1988, p. 267). Em resumo, o resultado da barganha das reformas judiciais de 1988 foi diretamente afetado por fatores sociais, culturais e históricos que eram relacionados ao fenômeno de path dependence.

Em conclusão, path dependence pode determinar quais estratégias estarão disponíveis para os formuladores de políticas públicas. Mais especificamente, existem situações em que uma seqüência particular de eventos pode, ao mesmo tempo, abrir uma janela de oportunidade para promover reformas, mas ao mesmo tempo forçar reformas a favorecerem um entre dois ou mais objetivos de reforma que estejam em conflito. Esse parece ter sido o caso do processo de reforma judicial no Brasil a partir de 1987.

\section{EVITANDO AS ARMADILHAS DE REFORMA}

$\mathrm{Na}$ seção II, ressaltou-se como as reformas seqüenciais podem produzir efeitos inesperados e indesejados, ao criar obstáculos para futuras reformas que terminam por prejudicar o projeto mais amplo de reforma a longo prazo (reformas-armadilha). Na seção III, mostrou-se que uma possível solução seria evitar reformas seqüenciais, mas essa solução é complicada pelo fato de reformas integrais também apresentarem riscos. Além disso, em alguns casos esse tipo de reforma não é sequer viável em virtude de uma série de obstáculos associados ao fenômeno de path dependence. Nesta seção, discute-se se há outras possibilidades de escapar desse tipo de armadilha em processos de reforma institucional. Mais especificamente, formulam-se hipóteses sobre quais fatores podem ter desempenhado um papel significativo na resolução do impasse da reforma judicial brasileira, e sustenta-se que o exemplo do Brasil pode iluminar possíveis soluções para impasses semelhantes em outros processos de reforma seqüencial.

A análise está primordialmente centrada naqueles fatores que poderiam levar os grupos de interesse que oferecem resistência às reformas a modificarem as suas preferências. Se considerarmos reformas institucionais como barganhas, conforme discutido acima, uma possível estratégia seria fortalecer o lado mais fraco do processo de barganha (DANIELS \& TREBILCOCK, 2004, p. 129-133) ${ }^{41}$. Independente de quão eficaz essa estratégia possa vir a ser, nada impede a consideração de outras possíveis estratégias para influenciar opositores a mudar seu posicionamento com relação à reforma. Nas subseções que se seguem, identificam-se três cenários em que essa mudança de posicionamento poderia ocorrer. O

41 Ver também Prado e Trebilcock (2009, p. 370-371). 
primeiro cenário e parte do terceiro cenário são baseados em hipóteses levantadas por Trebilcock e Daniels (2008). O segundo cenário e a metade do terceiro cenário são contribuições nossas a essa linha de pesquisa, e são particularmente relevantes para este artigo, porque elas podem explicar o que levou os juízes brasileiros a finalmente abandonarem a sua resistência ao controle externo do poder Judiciário.

\section{IV.1. Reduzindo os custos de conversão}

Uma forma de superar a resistência de grupos de interesse seria a redução dos custos que os mesmos iriam incorrer caso as reformas fossem implementadas. Como explicado por Trebilcock e Daniels: "Se diversos dos atores atualmente vinculados a certas instituições do Estado de Direito apresentarem preocupações legítimas de que serão sumariamente demitidos, ou de que perderão privilégios ilegítimos a que têm ou tiveram acesso em virtude do cargo público caso as novas instituições sejam criadas, então a resistência às reformas será provavelmente ainda mais intensa" (idem, p. 133) ${ }^{42}$.

Se os custos a serem incorridos por esses atores forem reduzidos, é provável que eles ofereçam menos resistência à implementação de reformas. Por exemplo, uma maneira de reduzir os custos para aqueles indivíduos que demonstrem falta de experiência ou preparo técnico para assumir papéis em novas instituições seria oferecer uma combinação de treinamento, compensação e mecanismos de accountability caso eles sintam-se prejudicados. Outra forma de reduzir esses custos seria oferecer assistência durante períodos de transição, na forma de compensações, benefícios relacionados à aposentadoria antecipada, apoio para recolocação e subsídios para cursos de treinamento para uma nova função dentro da mesma instituição (idem, p. 133134).

Ainda que essas estratégias sejam potencialmente eficazes em muitos casos, elas não parecem aplicáveis ao tipo de armadilha ou impasse de reforma ocorrido no caso brasileiro. Nesse caso, havia muito pouco a ser oferecido aos grupos de interesse do poder Judiciário para facilitar a transição: cursos de treinamento não tornariam os juízes mais accountables; os salários de magistrados já estavam entre os mais altos no país, tornando impossível a concessão de

\footnotetext{
42 Tradução livre do original em inglês: "If the many actors who are currently involved in a country's rule of law institutions legitimately fear that they will be summarily displaced or the illegitimate perquisites of public office eliminated when new institutions are created, then their resistance to reform is likely to be all the more intense".
}

mais benefícios ${ }^{43}$; é difícil imaginar um esquema de compensações semelhante à oferta de ações a funcionários em uma companhia recém-privatizada (buy-out), por exemplo. A única maneira realista de reduzir os custos para desarmar a armadilha de reformas no Brasil seria oferecer algo como benefícios para aposentadoria antecipada, o que poderia modificar a composição do quadro de juízes na ativa, tema que se discute a seguir.

\section{IV.2. Mudanças na composição de grupos de interesse}

Um aspecto importante em qualquer processo de reforma institucional é o papel desempenhado por idéias. Por um lado, algumas idéias podem fortalecer o lobby de certos grupos de interesse (DANIELS \& TREBILCOCK, 2004). Por outro lado, algumas idéias podem desempenhar o papel de mitigar a resistência de outros grupos. Como sugerido anteriormente, muitos atores do poder Judiciário brasileiro acreditavam que a independência judicial era mais importante que qualquer forma de controle do poder Judiciário. Dessa forma, mitigar a resistência desse grupo exigiria uma mudança nas opiniões e valores associados à independência judicial.

Uma maneira de influenciar os valores de um grupo é alterando a sua composição. À medida que juízes mais velhos - que foram vinculados ao regime militar - aposentam-se e juízes mais novos - que nasceram e cresceram durante o período democrático - passam a compor o poder Judiciário, a balança de preferências entre os integrantes dessa instituição pode começar a inclinar a favor de mais accountability. De fato, com base em pesquisas de opinião realizadas entre membros do poder Judiciário, em 2005, Joaquim Falcão mostra que havia uma divergência significativa de opinião sobre a importância da independência judicial entre juízes (que integram os escalões mais baixos dos tribunais e tendem a ser mais jovens), e desembargadores (que integram os tribunais superiores e tendem a ser mais velhos). A diferença de opinião entre esses dois grupos não se restringia à independência, mas também se aplicava a outros temas, tais como controle de corrupção e abusos: enquanto

43 Os membros do poder Judiciário brasileiro recebem os salários mais altos entre os funcionários públicos de todos os ramos do governo. Em dezembro de 2006, os ministros do Supremo Tribunal Federal ganhavam duas vezes mais do que os representantes do Congresso Nacional e três vezes mais do que o presidente da república. Os salários dos juízes está muito acima da média nacional. De acordo com o Banco Mundial, o valor dos salários dos juízes brasileiros em 1999 era mais de 30 vezes superior ao salário médio no país (WORLD BANK, 1999, p. 23). Esses mesmos resultados foram confirmados em 2004 (MARCONI, CARRILHO \& CAVALIERI, 2004). 
$71 \%$ dos juízes das cortes mais baixas declararam-se contra o nepotismo, apenas 58,4\% dos desembargadores declararam apoiar a proibição de nepotismo no poder Judiciário (FALCÃO, 2006, p. 125-127). O número de juízes mais jovens tem crescido progressivamente desde 1988 (a maioria deles nos tribunais inferiores): em 2005, 28,4\% dos juízes tinham 40 anos ou menos e 53,1\% tinham mais de 50 anos de idade (ibidem). De acordo com Falcão, juízes mais jovens são mais sensíveis às demandas populares por uma atitude mais ética e por maiores garantias de proteção do interesse público nos diversos ramos do governo. Esses dados podem explicar, ainda que parcialmente, porque uma parcela do próprio poder Judiciário brasileiro mudou de opinião e apoiou alguma forma de controle externo a partir do final da década de $1990^{44}$. Caso essa hipótese seja confirmada, uma forma de acelerar esse processo de "rejuvenescimento" interno, mudando idéias e valores em uma instituição que resiste a reformas, seria a oferta de incentivos para aposentadoria antecipada a membros mais antigos.

Os juízes mais novos não tinham muito poder ou canais institucionais de influência na estrutura hierárquica do poder Judiciário. No entanto, eles adquiriram poder político significativo ao criar associações profissionais de juízes (que são organizações da sociedade civil fora da estrutura formal do poder Judiciário) (idem $)^{45}$. As associações de juízes foram uma inovação institucional não contemplada especificamente na Constituição de 1988. Apesar disso, essas associações tornaram-se politicamente relevantes ao representar o interesse de juízes em discussões sobre projetos de lei e projetos de emendas constitucionais apresentados ao Congresso Nacional e ao facilitar uma maior presença midiática para os juízes mais novos. Devido ao fato de que essas associações não refletem a hierarquia formal do poder Judiciário, os juízes mais jovens puderam assumir posições de poder nessas estruturas. Essas associações de juízes passaram a representar primordialmente as opiniões e preferências dos juízes mais novos, de modo que os juízes mais velhos formaram sua própria associação, para melhor proteger e promover os seus interesses (DESEMBARGADORES CRIAM A ANDEs, 2006). Essas associações parecem ter sido um vetor importante na redução da resistência judicial a um maior grau de accountability. Como explicado por

\footnotetext{
44 Não há estudos investigando se juízes mais jovens desempenharam algum papel ativo na promoção de mecanismos de accountability no poder Judiciário brasileiro.

45 Ver também Koerner (1999).
}

Baillard: “Apesar da ampla oposição por parte de juízes, tanto a Associação dos Magistrados do Brasil (AMB) quanto outro grupo de juízes, a Associação dos Juízes Federais (Ajufe) recentemente capitularam à idéia do controle externo [...] a AMB declarou sua intenção em considerar um conselho supervisor formado por juízes, mas admitiu que advogados também possam fazer parte do órgão que deverá eleger os juízes que irão compor esse conselho. A Ajufe foi além, ao declarar, em janeiro de 1999, que iria apoiar um órgão de supervisão para questões administrativas (BALLARD, 1999, p. 264) ${ }^{46}$.

Esse é um exemplo claro de uma inovação institucional que deu voz a juízes mais jovens dentro do poder Judiciário brasileiro. A mesma emenda constitucional que criou o conselho externo da magistratura também modificou algumas das estruturas de governança interna dos tribunais superiores para permitir maior participação de juízes mais jovens 47 . Portanto, "rejuvenescer" uma organização que resiste a reformas com sangue fresco e idéias novas pode exigir medidas institucionais criativas que empoderem os novos membros e criem oportunidades para que eles possam expressar suas preferências mais eficazmente.

\section{IV.3. Disponibilizando informação}

Para Trebilcock e Daniels (2008), reformas visando aperfeiçoar instituições do Estado de Direito devem priorizar sistemas de avaliação de desempenho que sejam pertinentes, independentes e transparentes, a fim de melhor analisar quais instituições estão operando de modo eficiente e livre de corrupção e outros abusos. Por um lado, o caso brasileiro confirma a tese de que falta de transparência e accountability levam ao mau uso de recursos e a uma série de casos de abusos e corrupção (DANIELS \& TREBILCOCK,

\footnotetext{
46 Tradução livre do original em inglês: "Despite widespread opposition of judges, both the AMB [Brazilian association of Magistrates] and another group of judges, the Association of Federal Judges (AJUFE), recently capitulated to the idea of external control. [...] The AMB stated its willingness to consider an oversight council made up of judges but conceded that lawyers could play a role in selecting judges. The federal judges organization went a step further when it stated in January 1999 that it would support an oversight body to manage administrative questions".

47 Ver, por exemplo, Constituição Federal do Brasil de 1988, art. 93, XI, estabelecendo que as vagas nos órgãos especiais de administração dos tribunais com mais de vinte e cinco juízes serão providas metade pelo critério de antiguidade e metade via eleição pelo tribunal pleno. Esse sistema substituiu outro em que as vagas nos órgãos especiais de administração eram providas apenas pelo critério de antiguidade.
} 
2004). Por outro lado, o caso brasileiro também mostra que aqueles que querem promover reformas podem estar impedidos de implementar os mecanismos de accountabilty propostos por Daniels e Trebilcock (ao menos durante a primeira geração de reformas). Nessa subseção, questiona-se se mais informação pode ajudar a reduzir a resistência de grupos de interesse e criar oportunidades para uma segunda geração de reformas institucionais. No Brasil, a série de escândalos de corrupção e a divulgação de informação sobre casos de nepotismo e má gestão de recursos claramente fortaleceu a posição de grupos que eram favoráveis à criação de mecanismos para trazer maior accountability ao poder Judiciário. A questão colocada aqui, todavia, é distinta: o maior acesso à informação teria também ajudado a reduzir a resistência contra reformas oferecida por grupos de interesse?

Maior transparência pode facilitar uma segunda geração de reformas quando a divulgação de informações sobre corrupção, má gestão de recursos e abusos de poder tiveram um impacto negativo na reputação dos atores envolvidos, reduzindo, de acordo com Daniels e Trebilcock (idem), os incentivos desses atores para continuar apoiando o status quo. Essa parece ser uma descrição correta, ainda que parcial, do que aconteceu no caso brasileiro. Alguns autores sugerem que a crescente perda de apoio popular e de legitimidade do poder Judiciário pode explicar a mudança parcial de posicionamento dos juízes brasileiros. Uma série de escândalos envolvendo membros do poder Judiciário, especialmente a partir do final da década de 1990, levou à criação de uma Comissão Parlamentar de Inquérito para investigar casos de corrupção e outras formas de abuso por juízes, o que abalou ainda mais a confiança popular nos tribunais, que já estava em declínio (TAYLOR, 2005, p. 43) ${ }^{48}$. Juízes que não estavam envolvidos em favoritismo e corrupção parecem ter decidido que era importante diferenciar-se do resto do poder Judiciário por meio do apoio expresso a propostas de criação de mecanismos de accountability. Dessa forma, impactos negativos sobre a reputação podem potencialmente explicar por que parcelas crescentes do poder Judiciário começaram a favorecer propostas por um conselho judicial externo a partir do final da década de $1990^{49}$.

Outra razão pela qual a disponibilidade de informação pode ajudar a reduzir a resistência a reformas está relacionada à existência de fatores

\footnotetext{
48 Ver também Ballard (1999).

49 O caso brasileiro sugere que acesso a informação apenas não é suficiente. É necessário que aqueles que têm acesso a essa informação tenham a capacidade de fazer uso efetivo da mesma (o que normalmente requer acesso a recursos).
}

sociais, culturais e históricos que são adversos às reformas. A idéia de impacto negativo na reputação, discutida acima, separa os juízes que estão em busca de rendas ilícitas ou ilegítimas (rent-seeking) dos demais juízes; nesse caso, a disponibilidade de informação aumenta os custos de resistência a reformas também entre aqueles juízes que estão atualmente beneficiando-se ilegalmente ou ilegitimamente do status quo. A idéia de impacto negativo sobre a reputação evidencia dessa forma os fatores de economia política por trás da mudança de posicionamento dos juízes brasileiros. Em contraste, a tese dos fatores sociais, culturais e históricos sustenta que juízes honestos também podem resistir a reformas. Diferentemente daqueles que se beneficiam de maneira ilícita ou ilegal do status quo, esses privilegiariam a independência judicial em detrimento do controle judicial com base em princípios, e não por causa de interesses individuais. É mais complexo explicar uma redução na resistência a reformas quando ela está baseada em princípios, mas essa mudança pode estar relacionada ao maior acesso à informação. Por exemplo, um juiz honesto e bem-intencionado, que acredita na importância de fortes garantias à independência judicial, pode se ver forçado a reconsiderar seu posicionamento à luz de informações demonstrando que os abusos, nepotismo e corrupção tornaram-se sistêmicos no sistema judicial. Se valores e interesses forem considerados dinâmicos e endógenos ao processo político, a disponibilidade de informação pode providenciar incentivos para os atores repensarem os próprios valores.

\section{CONCLUSÕES}

Não há como promover o desenvolvimento econômico e social, em longo prazo, sem instituições adequadas. No entanto, nós ainda sabemos muito pouco sobre como promover e implementar reformas institucionais que persistam no tempo e que conduzam eficazmente à melhoria dos indicadores de desenvolvimento. $\mathrm{O}$ histórico das inúmeras tentativas frustradas para promover reformas que venham a fortalecer as instituições do Estado de Direito é desanimador. $\mathrm{O}$ trabalho desenvolvido por Michael Trebilcock e Ron Daniels (2008) contribuiu para aprofundar o nosso entendimento sobre os obstáculos que podem explicar esse recorde negativo. Em seu último livro, os autores mapearam esses obstáculos às reformas institucionais em geral, e mais especificamente aqueles obstáculos às tentativas de promover reformas de instituições do Estado de Direito. Neste artigo, utilizou-se o mapeamento desenvolvido por Trebilcock e Daniels (idem) para discutir uma situação paradoxal: reformas iniciais causando efeitos indesejados, prejudicando os esforços de reforma mais 
amplos, e criando obstáculos para uma segunda geração de reformas (reformas-armadilha). Também se explorou como esses obstáculos foram superados no caso brasileiro e quais lições nossa experiência pode oferecer para outros países em desenvolvimento. Apesar das dificuldades de generalizar a partir de estudos de caso, tais estudos parecem ser um dos caminhos mais promissores para o Direito e o desenvolvimento (TREBILCOCK \& PRADO, 2011, cap. 8). E as reformas institucionais no Brasil oferecem um prato cheio para os pesquisadores dessa área, como se espera ter demonstrado nesse artigo ${ }^{50}$.

$50 \mathrm{O}$ final desse artigo foi modificado para melhor se adequar ao propósito da publicação no Brasil (Nota da Autora).

Mariana Mota Prado (mariana.prado@utoronto.ca) é professora associada da Faculdade de Direito da Universidade de Toronto (Canadá).

\section{REFERÊNCIAS BIBLIOGRÁFICAS}

BALLARD, M. J. 1999. Clash between Local Courts and Global Economics: The politics of judicial reform in Brazil. Berkeley Journal of International Law, Berkeley, v. 17, n. 2, p. 230-276. Disponível em: http://scholarship.law.berkeley.edu/cgi/ viewcontent.cgi article $=1180 \&$ context $=$ bjil. Acesso em: 6.maio.2013.

CAROTHERS, T. 1998. The Rule of Law Revival. Foreign Affairs, Buffalo, v. 77, n. 2, p. 95-106, Mar.-Apr.

2002. The End of the Transition Paradigm. Journal of Democracy, Baltimore, v. 13, n. 5, p. 5-21, Jan. Disponível em: http:// terpconnect.umd.edu/ dcrocker/Courses/Docs/ PUAF698Q-Carothers.pdf. Acesso em: 6.maio.2013.

DANIELS, R. \& TREBILCOCK, M. 2004. The Political Economy of Rule of Law Reform in Developing Countries. Michigan Journal of International Law, Ann Arbor, v. 26, p. 99-140. Disponível em: FALCÃO, J. 2006. O múltiplo judiciário. In: SADEK, M. T. (ed.). Magistrados: uma imagem em movimento. Rio de Janeiro: FGV.

FEREJOHN, J. A. \& KRAMER, L. D. 2002. Independent Judges, Dependent Judiciary: Institutionalising Judicial Restraint. New York Law Review, New York, v. 77, n. 4, p. 962-1039, Oct. Disponível em: http://siteresources.worldbank.org/ I N T L A W J U S T I N S T/R e s o u r c e s/ ferejohn_kramer.pdf. Acesso em: 6.maio.2013.

FISS, O. M. 1993. The Right Degree of Independence. In: STOTZKY, I. P. (ed.). Transition to Democracy in Latin America: The rule of the judiciary. Boulder: Westview.

GAROUPA, N. \& GINSBURG, T. 2009a. The Comparative Law and Economics of Judicial Councils. Berkeley Journal of International Law, Berkeley, v. 27, n. 1, p. 53-83. Disponível em: http://scholarship.law.berkeley.edu/cgi/ viewcontent.cgi article $=1364 \&$ context $=b j i l$. Acesso em: 6.maio.2013.

2009b. Guarding the Guardians: Judicial Councils and Judicial Independence. The American Journal of Comparative Law, Ann Arbor, v. 57, n. 1, p. 201-232, Winter.

GARTH, B \& DEZALAY, Y. 2002. Introduction. In: DEZALAY, Y. \& GARTH, B. (eds.). Global Prescriptions: The production, exportation and importation of a new legal orthodoxy. Ann Arbor: University of Michigan.

KOERNER, A. 1999. O debate sobre a reforma judiciária. Novos Estudos, São Paulo, v. 54, n. 5, p. 11-26, jul. Disponível em: http:// www.novosestudos.com.br/v1/files/uploads/ contents/88/20080627_o_debate_sobre_ a_reforma.pdf. Acesso em: 6.maio.2013.

LAMOUNIER, B. 1994. Brazil at an Impasse. Journal of Democracy, Baltimore, v. 5, n. 3, p. 72-87, July.

LARKINS, C. 1996. Judicial Independence and Democratization: A theoretical and conceptual analysis. The American Journal of Comparative Law, Ann Arbor, v. 44, n. 4, p. 605-626, Autumn.

LIMA, M. 2000. Judiciário e Estado no Brasil: tribunais superiores e juízes na formação do Estado brasileiro. Pensar, Fortaleza, v. 5, n. 1, p. 87-121. Disponível em: http://ojs.unifor.br/index.php/rpen/ article/view/1110/1947. Acesso em: 6.maio.2013.

MAINWARING, S. 1997. Multipartism, Robust Federalism, and Presidentialism in Brazil. In: MAINWARING, S. \& SHUGART, M. (eds.). Presidentialism and Democracy in Latin America. Cambridge (UK): Cambridge University.

MARCONI, N.; CARRILHO, L. \& CAVALIERI, C. H. 2004. La remuneración de los altos dirigentes del sector público: una análisis sobre los países de 
America Latina y el Caribe. Lima: Centro Latinoamericano de Administración para el Desarrollo. Disponível em: http://epoca.globo.com/ rev_eletronica/ep446/judiciario.pdf.

NORTH, D. 1986. The New Institutional Economics. Journal of Institutional and Theoretical Economics, Tübingen, v. 142, n. 1, p. 230-237, Mar.

1990. Institutions, Institutional Change and Economic Performance. Cambridge (UK): Cambridge University.

OLIVEIRA, M. A. J. S. C. 2006. Reforming the Brazilian Supreme Federal Court: A comparative approach. Washington University Global Studies Law Review, Washington (DC), v. 5, n. 1, p. 99150. Disponível em: http://digitalcommons.law. wustl.edu/cgi/viewcontent.cgi? article $=1171$ \&context=globalstudies. Acesso em: 6.maio.2013.

PEREIRA, A. 2003. Explaining Judicial Reform Outcomes in New Democracies: The importance of authoritarian legalism in Argentina, Brazil, and Chile. Human Rights Review, New York, v. 4, n. 3, p. 2-16, Apr.-June.

2008. Of Judges and Generals: Security courts under authoritarian regimes in Argentina, Brazil, and Chile. In: GINSBURG, T. \& MOUSTAFA, T. (eds.). Rule by Law: The politics of courts in authoritarian regimes. Cambridge (UK): Cambridge University.

PEREZ-PERDOMO, R. Judicial Independence and Accountability. In: PUYMBROECK, R. V. V. (ed.). Comprehensive Legal and Judicial Development: Toward an agenda for a just and equitable society in the 21 st Century. Washington (DC): World Bank. Disponível em: http://siteresources.worldbank.org/ BRAZILINPOREXTN/Resources/38171661185895645304/4044168-1186409169154/ 02ConferenceProceedings.pdf. Acesso em: 6.maio. 2013 .

PILATTI, A. 2008. A Constituinte de 1987-1988: progressistas, conservadores, ordem econômica e regras do jogo. Rio de Janeiro: PUC-Rio.

PINHO, J. A. G. \& SACRAMENTO, A. R. S. 2009. Accountability: já podemos traduzi-lo para o português? Revista de Administração Pública, Rio de Janeiro, v. 43, n. 6, p. 1343-1368, nov.-dez. Disponível em: http://www.scielo.br/pdf/rap/ v43n6/06.pdf. Acesso em: 6.maio.2013.

POWER, T. J. 1997. Why Brazil Slept: The search for political institutions, 1985-1997. Trabalho apresentado no Encontro da Associação de Estudos
Latino Americanos, realizado em Guadalajara, México, de 17 a 19 de abril. Digit. Disponível em: http://biblioteca.clacso.edu.ar/ar/libros/lasa97/ power.pdf. Acesso em: 6.maio.2013.

PRADO, M. M. 2008. Policy and Politics: The privatization of the electricity sector in Brazil. New Haven. Tese (Doutorado em Direito Internacional). Yale Law School.

PRADO, M. M. \& TREBILCOCK, 2009. M. Path Dependence, Development, and the Dynamics of Institutional Reform. University of Toronto Law Journal, Toronto, v. 59, n. 3, p. 341-379, Apr.

PRILLAMAN, W. C. 2000. The Judiciary and Democratic Decay in Latin America: Declining confidence in the rule of law. Westport: Praeger.

ROSE-ACKERMAN, S. 2008. Corruption and PostConflict Peace-Building. Yale Law School Review, New Haven, v. 34, p. 405-443. Disponível em: http://digitalcommons.law.yale.edu/fss_papers/ 593/. Acesso em: 6.maio.2013.

ROSENN, R. 2000. Judicial Review in Brazil: Developments under the 1988 Constitution. Southwestern Journal of Law \& Trade in the Americas, Los Angeles, v. 7, p. 291-299.

SANTISO, C. 2003. Economic Reform and Judicial Governance in Brazil: Balancing independence with accountability. Democratization, Abingdon, v. 10, n. 4, p. 161-180, June.

SEN, A. 1990. Gender and Cooperative Conflict. In: TINKER, I. (ed.). Persistent Inequalities: Women and World Development. New York: Oxford University.

SKIDMORE, T. 1988. The Politics of Military Rule in Brazil, 1964-85. New York: Oxford University.

SOUZA, A. S. 1998. Collor's Impeachment and Institutional Reform in Brazil. In: ROSENN, K. S. \& DOWNES, R. (eds.). Corruption and Political Reform in Brazil: The impact of Collor's impeachment. Coral Gables: North-South Center.

SUTIL, J. C. 1993. The Judiciary and the Political System in Chile: The dilemmas of judicial independence during the transition to democracy. In: STOTZKY, I. P. (ed.). Transition to Democracy in Latin America: The rule of the judiciary. Boulder: Westview.

TAMANAHA, B. 2004. On the Rule of Law: History politics, theory. Cambridge (UK): Cambridge University.

2009. The Primacy of Society and the Failure 
of Law and Development. Cornell International Law Journal, Ithaca, v. 44, n. 2, p. 209-247, Spring. Disponível em: http://www.lawschool. cornell.edu/research/ilj/upload/tamanaha-final.pdf. Acesso em: 6.maio.2013.

TARR, G. A. 2006. Creating and Debating Judicial Independence and Judicial Accountability. Trabalho apresentado no Encontro Anual da American Political Science Association, realizado na Filadélfia, Estados Unidos, de 30 de agosto a 4 de setembro. Digit.

TAYLOR, M. M. 2005. Citizens Against the State: The riddle of high impact, low functionality courts in Brazil. Brazilian Journal of Political Economy, São Paulo, v. 25, n. 4, p. 418-438, Oct-Dec. Disponível em: http://www.scielo.br/pdf/rep/ v25n4/28292.pdf. Acesso em: 6.maio.2013.

2008. Judging Policy: Courts and policy reform in Democratic Brazil. Stanford: Stanford University.

TAYLOR, M. M. \& BURANELLI, V. C. 2007.
Ending Up in Pizza: Accountability as a problem of institutional arrangement in Brazil. Latin American Politics \& Society, Oxford, v. 49, n. 1, p. 59-87, Apr.

TRUBEK, D. 2006. The Rule of Law in Development Assistance: Past, present and future. In: TRUBEK, D \& SANTOS, A. (eds.). The New Law and Economic Development: A critical appraisal. Cambridge (UK): Cambridge University.

TREBILCOCK, M. 1997. What Makes Poor Countries Poor: The role of institutional capital in economic development. In: BUSCAGLIA, E. \& COOTER, R. (eds.). The Law and Economics of Development. Greenwich: JAI.

TREBILCOCK, M. \& DANIELS, R. 2008. Rule of Law Reform and Development: Charting the fragile path of progress. Cheltenham: Edward Elgar.

TREBILCOCK, M. J. \& PRADO, M. M. 2011. What Makes Poor Countries Poor? Institutional Determinants of Development. Edward Elgar.

\section{OUTRAS FONTES}

BRASIL. Ação Direta de Inconstitucionalidade 3367/ 2004

BRASIL. Constituição Federal de 1988.

BRASIL. Emenda Constitucional n. 45, de 2004 (EC000.045-2004)

BRASIL. Lei Orgânica da Magistratura Nacional (LOMAN), art. 26, c. II.

BRASIL. CONGRESSO NACIONAL. 2000. Resultados dos Trabalhos da Comissão Parlamentar de Inquérito sobre o Poder Judiciário. Brasília: Senado Federal.
Desembargadores criam a Andes, associação nacional da classe. Consultor Jurídico, 10.mar. Disponível em: http://www.conjur.com.br/2006-mar-10/ desembargadores_criam_associacao_nacional_classe. Acesso em: 6.maio.2013.

WORLD BANK. Court Performance around the World - A Comparative Perspective. World Bank Technical Paper, Washingon (DC), n. 430, p. 172, July. Disponível em: http://siteresources. worldbank.org/BRAZILINPOREXTN/Resources/ 3817166 - $1185895645304 / 4044168$ $1186404259243 / 14$ pub_br176.pdf. Acesso em: 6.maio. 2013 .

\section{QN

